\title{
STUDI IN VITRO BAKTERI ASAM LAKTAT KANDIDAT PROBIOTIK DARI MAKANAN FERMENTASI INDONESIA
}

\author{
[In Vitro Evaluation of Probiotic Candidate Bacteria from Indonesian Food]
Gunawan Priadi*, Fitri Setiyoningrum, Fifi Afiati, Rohmatussolihat Irzaldi, dan Puspita Lisdiyanti

Pusat Penelitian Bioteknologi Lembaga IImu Pengetahuan Indonesia, Cibinong, Bogor

Diterima 6 Agustus 2019 / Disetujui 6 Februari 2020

\begin{abstract}
Indonesia has a rich variety of fermented foods. The lactic acid bacteria contained in such fermented foods can act as probotics providing positive effects on digestive health. Lack of information about the characteristics of the native $L A B$ caused insufficient use of them in functional food products. The purpose of this study was to carry out in vitro selection of potential probiotics of lactic acid bacteria isolated from non-dairy fermented foods i.e. pickle, cassava tape, terasi and dadih. The probiotic property tests are acid and bile salt tolerance assays, hydrophobicity test, adhesion test and coaggregation test. LAB isolates passing all tests indicate that they are potential as probiotics. This study obtained 4 LABs having probiotics properties by in vitro tests, i.e. L. plantarum LIPI12-2-LAB004 from pickle (Yogyakarta), L. plantarum LIPI12-2-LAB031 from cassava tape (Yogyakarta), L. plantarum LIPI13-2-LAB011 from terasi (Bali), and L. plantarum LIPI13-2-LAB087 from terasi (Solok). The four $L A B$ were able to survive high acid and bile salt concentrations above $85 \%$, had hydrophobicities above $95 \%$, capable of adhering to solid surfaces for 24 hours, and were able to co-aggregate with other $\angle A B$ isolates.
\end{abstract}

Keywords: adhesion, bile salt, coagregation, hidrofobicity, probiotic properties

\section{ABSTRAK}

Indonesia memiliki beragam makanan fermentasi yang kaya akan manfaat. Kandungan bakteri asam laktat (BAL) pada makanan tersebut mampu memberikan dampak positif pada kesehatan saluran pencernaan sebagai probiotik. Informasi karakteristik BAL asli Indonesia yang sedikit menyebabkan belum banyaknya pemanfaatan BAL ters ebutmenjadi produk pangan fungsional. Tujuan dari penelitian ini adalah menyeleksi BAL yang potensial sebagai probiotik secara in vitro yang berasal dari pangan fermentasi bukan produk susu yaitu acar, tape singkong, terasi dan dadih. Uji karakteristik probiotik yang dilakukan adalah daya tahan hidup pada kondisi asam dan garam empedu konsentrasi tinggi, uji hidrofobisitas, uji penem pelan pada lempeng tipis dan uji koagreasi. Jika isolat BAL lolos semua pengujian mengindikasikan bahwa isolat ters ebut bersifat probiotik. Hasil penelitian memperoleh 4 BAL yang bersifat probiotik (secara in vitro) yaitu L. plantarum LIPI12-2-LAB004 yang diisolasi dari acar Yogyakarta, L. plantarum LIPI12-2LAB031 dari tape singgkong Yogyakarta, L. plantarum LIPI13-2-LAB011 dari terasi Bali dan L. plantarum LIPI13-2-LAB087 dari terasi Solok. Keem pat BAL ters ebut mampu bertahan pada kondisi asam dan garam konsentrasi tinggi di atas $85 \%$, memiliki kemampuan hidrofobisitas di atas $95 \%$, mampu menempel pada lempeng tipis selama 24 jam, dan mampu berkoagregasi dengan isolat BAL lainnya.

Kata kunci: garam empedu, hidrofobisitas, koagregasi, penempelan, probiotik

\section{PENDAHULUAN}

Pengembangan produk pangan saat ini berfokus dalam menciptakan produk pangan fungsional. Salah satu pangan yang dikembangkan adalah makanan yang mengandung probiotik. Produk makanan yang telah diketahui memiliki kandungan

*Penulis Korespondensi:

E-mail: gunawan.priadi@ymail.com probiotik adalah produk fermentasi susu oleh bakteri asam laktat (BAL) seperti yogurt, kefir dan dadih. Probiotik diartikan sebagai mikroba hidup yang dalam jumlah cukup mampu memberikan manfaat bagi inangnya (Fijan, 2014). Manfaat probiotik didapat jika mengonsumsi makanan yang mempunyai kandungan probiotik $10^{6}-10^{7}$ per $\mathrm{mL}$ atau $\mathrm{g}$ (Lähteinen et al., 2010). Mikroba BAL mempunyai potensi yang besar sebagai probiotik. 
Penelitian tentang sumber BAL yang berpotensi sebagai probiotik diantaranya berasal dari produk susu (Kaur et al., 2017), makanan fermentasi (Yang et al., 2017), bagian buah dan sayuran (Pundir et al., 2013), hewan dan bagian dari hewan (KizerwetterŚwida dan Binek, 2016) dan minuman (García-Ruiz et al., 2014). BAL menjadi pilihan dalam penelitian pengembangan produk fungsional karena karakteristiknya yang aman dan telah ditetapkan dalam generally recommended as safe (GRAS) (Fijan, 2014). Manfaat probiotik diantaranya menjaga keseimbangan mikroflora saluran pencernaan, mencegah diare, menurunkan kadar kolesterol, tidak menimbulkan iritasi pada usus, berpotensi sebagai anti kanker, meningkatkan kekebalan tubuh, membantu menjaga berat tubuh, dan produk susu fermentasi BAL dapat membantu bayi yang alergi dan intoleran terhadap susu.

Pangan fermentasi merupakan sumber bakteri probiotik baru yang dapat digunakan untuk memproduksi berbagai macam pangan fungsional. Bakteri ini dapat dikonsumsi dan bermanfaat bagi kesehatan. Proses fermentasi mengubah karakteristik fisikokimia, mikrobiologis dan organoleptik dari bahan yang difermentasi. Fermentasi pangan bertujuan untuk diversifikasi produk dan memperpanjang umur simpan. Tujuan lainnya adalah untuk meningkatkan kecernaan dan nutrisi serta menambah kebaikan nilai organoleptik seperti flavor, aroma, dan tekstur produk (Nuraida, 2015). Indonesia memiliki banyak makanan fermentasi dari berbagai bahan seperti tape dari singkong dan beras; tempe, tauco, dan kecap dari kedelai; acar dari mentimun; terasi dari udang; oncom dari kacang tanah; dadih dari susu kerbau; brem dari beras; dan tempoyak dari buah durian. Mikroba yang berperan dalam pangan fermentasi Indonesia adalah khamir (tempe, tape, kecap, dan tauco), yeast (tape dan brem), bakteri (tape, dadih, dan terasi) dan campuran diantaranya. Penelitian terdahulu mengenai isolasi dan karakterisasi mikroba dalam pangan fermentasi Indonesia diantaranya dilakukan oleh Ismail dan Yulvizar (2017) dan Hartini et al. (2019). Penelitian karakteristik probiotik mikroba dari pangan fermentasi dapat memberikan manfaat dalam menambah alternatif pamanfaatan mikroba tersebut.

Pengujian in vitro yang digunakan dalam menentukan karakteristik probiotik mikroba diantaranya resisten terhadap keasaman lambung dan garam empedu, kemampuan untuk menempel pada saluran pencernaan, mempunyai aktivitas anti mikroba patogen atau menurunkan jumlah mikroba patogen, dan mempunyai aktivitas hidrolisis garam empedu (Kumar et al., 2015). Penelitian ini bertujuan untuk mengevaluasi dan menyeleksi secara in vitro karakteristik probiotik dari BAL yang berasal dari acar, tape singkong, terasi dan dadih. Sebanyak 7 isolat BAL dari makanan fermentasi diujikan karakteristik probiotiknya yaitu ketahanan hidup pada konsentrasi keasaman dan garam empedu yang tinggi, uji hidrofobisitas, uji penempelan pada lempeng tipis dan uji koagregasi.

\section{BAHAN DAN METODE}

\section{Bahan}

Tujuh isolat BAL diperoleh dari Indonesian Culture Collection (InaCC). Asal dan jenis BAL ditampilkan pada Tabel 1. Terdapat tiga spesies BAL yang digunakan yaitu Lactobacillus plantarum, Leuconostoc mesenteroides, dan Lactobacillus farciminis. Penelitian dilaksanakan di Pusat Penelitian Bioteknologi, LIPI.

Tabel 1. BAL yang digunakan untuk seleksi kandidat probiotik

\begin{tabular}{|c|c|c|c|}
\hline No. & $\begin{array}{l}\text { Nomor } \\
\text { Seri Isolat }\end{array}$ & Asal Isolat & Galur \\
\hline 1 & $\begin{array}{l}\text { LIPI12-2- } \\
\text { LAB004 }\end{array}$ & Acar, Yogyakarta & $\begin{array}{l}\text { Lactobacillus } \\
\text { plantarum }\end{array}$ \\
\hline 2 & $\begin{array}{l}\text { LIPI12-2- } \\
\text { LAB030 }\end{array}$ & $\begin{array}{l}\text { Tape singkong, } \\
\text { Yogyakarta }\end{array}$ & $\begin{array}{l}\text { Leuconostoc } \\
\text { mesenteroides }\end{array}$ \\
\hline 3 & $\begin{array}{l}\text { LIPI12-2- } \\
\text { LAB031 }\end{array}$ & $\begin{array}{l}\text { Tape singkong, } \\
\text { Yogyakarta }\end{array}$ & $\begin{array}{l}\text { Lactobacillus } \\
\text { plantarum }\end{array}$ \\
\hline 4 & $\begin{array}{l}\text { LIPI13-2- } \\
\text { LAB087 }\end{array}$ & $\begin{array}{l}\text { Terasi, Solok, } \\
\text { Sumbar }\end{array}$ & $\begin{array}{l}\text { Lactobacillus } \\
\text { plantarum }\end{array}$ \\
\hline 5 & $\begin{array}{l}\text { LIPI13-2- } \\
\text { LAB011 }\end{array}$ & Terasi, Bali & $\begin{array}{l}\text { Lactobacillus } \\
\text { plantarum }\end{array}$ \\
\hline 6 & $\begin{array}{l}\text { LIPI12-2- } \\
\text { LAB033 }\end{array}$ & $\begin{array}{l}\text { Tape singkong, } \\
\text { Yogyakarta }\end{array}$ & $\begin{array}{l}\text { Lactobacillus } \\
\text { farciminis }\end{array}$ \\
\hline 7 & $\begin{array}{l}\text { LIPI13-2- } \\
\text { LAB077 }\end{array}$ & $\begin{array}{l}\text { Dadih, Solok, } \\
\text { Sumbar }\end{array}$ & $\begin{array}{l}\text { Lactobacillus } \\
\text { plantarum }\end{array}$ \\
\hline
\end{tabular}

\section{Persiapan kultur bakteri}

Satu $\mathrm{mL}$ kultur stok bakteri ditumbuhkan pada 5 $\mathrm{mL}$ media de mann rogosa sharpe broth (MRS cair) (Merck, Germany) secara aseptis. Kultur bakteri diinkubasi (suhu $30^{\circ} \mathrm{C}, 48$ jam) menggunakan inkubator (Raypa, Spain). Kultur bakteri tersebut kemudian diambil $1 \mathrm{~mL}$ dan ditumbuhkan kembali ke dalam 5 $\mathrm{mL}$ media MRS cair, kemudian diinkubasi (suhu $30^{\circ} \mathrm{C}, 48$ jam). Kultur terakhir ini yang diujikan karakteristik probiotiknya.

\section{Ketahanan isolat BAL terhadap asam lambung dan garam empedu (modifikasi Kaur et al., 2017)}

Uji ketahanan hidup dalam konsentrasi keasaman tinggi dilakukan dengan mengambil $0,1 \mathrm{~mL}$ suspensi bakteri kandidat probiotik dari media de mann rogosa sharpe broth (MRS cair) (Merck, Germany) diinokulasikan kedalam $2 \mathrm{~mL}$ MRS cair $\mathrm{pH} 2,5(\mathrm{pH}$ diatur dengan menambahkan $\mathrm{HCl} 0,1 \mathrm{~N}$ (Merck, Germany). Kemudian diinkubasi (suhu $37^{\circ} \mathrm{C}$ ) dalam inkubator (Raypa, Spain). Total jumlah bakteri dihitung menggunakan metode total plate count (TPC) pada waktu inkubasi $0,4,8$, dan 24 jam 
menggunakan colony counter (J Selecta, Spain). Prosedur yang sama dilakukan untuk pengujian ketahanan terhadap garam empedu, tetapi $\mathrm{HCl}$ diganti dengan oxgall (Merck, Germany) sehingga konsentrasi oxgall dalam MRS cair menjadi 0,3\%. Perhitungan persentase bakteri yang mampu bertahan pada kondisi asam atau kondisi garam, menggunakan persamaan:

Tingkat Ketahanan $(\%)=\frac{\log C F U N_{1}}{\log C F U N_{0}} \times 100 \%$

dimana, $\mathrm{N}_{1}=$ Jumlah bakteri setelah perlakuan (jam ke-24); $\mathrm{N}_{0}=$ Jumlah bakteri awal (jam ke-0).

\section{Uji hidrofobisitas isolat BAL (Canzi et al., 2005)}

Kultur bakteri diperbanyak dengan menumbuhkan pada media de mann rogosa sharpe broth (MRS cair) (Merck, Germany). Kemudian diinkubasi (suhu $37^{\circ} \mathrm{C}, 24$ jam) di inkubator (Raypa, Spain). Pemanenan sel bakteri dilakukan dengan cara sentrifugasi pada $3500 \mathrm{~g}$ selama 10 menit menggunakan Multifuge X3R (Thermoscientific, USA). Pellet dibilas dan dilarutkan dalam phospate buffered saline (PBS) (Merck, Germany) hingga mencapai optical density (OD) 0,4-0,6 menggunakan spektrofotometer UV-Vis (Shimadzu, USA) dengan panjang gelombang 600 $\mathrm{nm}$. Tiga $\mathrm{ml}$ suspensi bakteri dimasukkan ke tabung uji steril dan ditambah $10 \mu \mathrm{L}$ heksadekana (Merck, Germany), dihomogenkan menggunakan vortex (Heidolph, Germany) 2 kali (satu kali homogenisasi 10 detik) dengan interval 5 detik. Suspensi bakteri didiamkan selama 10 menit agar terjadi pemisahan, kemudian diukur OD-nya menggunakan spektofotometer pada panjang gelombang $600 \mathrm{~nm}$. Bakteri yang berpindah ke heksadekana dihitung dengan persamaan:

Hidrofobisitas $=\frac{A_{0}-A}{A_{0}} \times 100 \%$

dimana, $A_{0}=$ Nilai OD $600 \mathrm{~nm}$ suspensi awal; $A=$ Nilai OD setelah dicampur heksadekana.

\section{Uji penempelan isolat BAL pada lempeng tipis (Dewanti dan Wong, 1995)}

Lempeng stainless stell (SS) dipotong dengan ukuran $3 \times 3 \mathrm{~cm}$, kemudian disterilisasi (suhu $121^{\circ} \mathrm{C}$, 15 menit) pada autoklaf (Raypa, Spain). Selanjutnya lempeng SS dimasukkan kedalam erlenmeyer yang berisi kultur isolat bakteri, kemudian diinkubasi dalam incubated benchtof (Thermo Fisher, USA) dengan kecepatan 150 rpm (suhu ruang, 24 jam dan 48 jam). Setelah waktu inkubasi lempeng SS diulas (swab) secara aseptis dan merata. Hasil ulas dima- sukkan kedalam larutan pengencer $\mathrm{NaCl}$ 0,85\% (Merck, Germany) untuk menghitung jumlah koloni dengan metode pour plate menggunakan media de mann rogosa sharpe agar (MRS agar) (Merck, Germany). Pengenceran dilakukan sampai 8 siklus log dan kemudian diinkubasi. Perhitungan jumlah mikroba dalam media cair (planktonic), diambil $1 \mathrm{~mL}$ cairan kultur dan diencerkan sampai 8 siklus log, kemudian diplating secara pour plate. Selanjutnya diinkubasi pada suhu $37^{\circ} \mathrm{C}$ dalam inkubator (Raypa, Spain) selama 24 dan 48 jam.

\section{Uji koagregasi isolat BAL (Kos et al., 2003)}

Kultur bakteri diperbanyak dengan menumbuhkan pada media de mann rogosa sharpe broth (MRS cair). Kemudian diinkubasi $\left(37^{\circ} \mathrm{C}, 24\right.$ jam) menggunakan inkubator (Raypa, Spain). Pemanenan kultur dilakukan dengan mensentrifugasi media MRS cair pada $10.000 \mathrm{~g}$ selama 10 menit menggunakan Multifuge X3R (Thermoscientific, USA). Selanjutnya dicuci dengan larutan penyangga fosfat $(\mathrm{NaCl} 8 \mathrm{~g} / \mathrm{L}$ (Merck, Germany), $\mathrm{KH}_{2} \mathrm{PO}_{4}$ 0,34 g/l (Merck, Germany), $\mathrm{K}_{2} \mathrm{HPO}_{4} 1,21 \mathrm{~g} / \mathrm{L}$ (Merck, Germany) sebanyak 2 kali. Kultur disuspensikan kembali dalam larutan penyangga yang sama. Kemudian kultur yang akan dipasangkan dicampur. Setelah pencampuran, kultur campuran dimasukkan kedalam kuvet dan dilihat penurunan optical density (OD) sampai 0,6 $\pm 0,02$ menggunakan spektofometer UV-Vis (Shimadzu, USA) dengan panjang gelombang $600 \mathrm{~nm}$. Pengamatan dilakukan selama 4 jam pada suhu ruang. Sebagai kontrol adalah kultur bakteri tunggal yang tidak dipasangkan. Nilai koagregasi dihitung dengan persamaan:

$$
\begin{aligned}
& \text { Koagregasi }(\%)= \\
& \frac{(O D .1+O D .2)-2 \times \text { OD. } 1.2}{\text { OD. } 1+\text { OD. } 2} \times 100 \%
\end{aligned}
$$

dimana, OD.1= OD galur bakteri 1; OD.2= OD galur bakteri 2; OD.1.2= OD campuran galur bakteri 1 dan 2 .

\section{Analisis data}

Variabel bebas dalam penelitian adalah jenis isolat dan waktu inkubasi. Data ketahanan isolat terhadap asam lambung dan garam empedu, uji hidrofobisitas dan uji penempelan diolah dengan SPSS 22 dan dianalisis keragamannya (uji analysis of varian (ANOVA)). Jika variabel bebas memberikan perbedaan pengaruh yang signifikan $(P<0,05)$ maka dilanjutkan dengan uji pembedaan duncan multiple range test (DMRT). Analisis deskripsi dilakukan untuk data uji koagregasi. 


\section{HASIL DAN PEMBAHASAN}

\section{Ketahanan isolat BAL terhadap kondisi asam dan konsentrasi garam}

Kriteria penting dalam seleksi kandidat probiotik adalah ketahanan bakteri terhadap kondisi saluran pencernaan. Lambung memiliki tingkat keasaman yang tinggi, sedangkan pada saluran usus halus terdapat cairan dengan konsentrasi garam yang tinggi. Kondisi tersebut dapat memengaruhi viabilitas sel bakteri. Keasaman tinggi dapat merusak membran sel dan komponen intraselular. Kondisi ini akan menyebabkan kematian pada bakteri yang tidak tahan asam (Hartini et al., 2019). Usus halus dan usus besar mempunyai konsentrasi garam empedu yang tinggi. Garam empedu dapat menembus membran sitoplasma yang menyebabkan rusaknya membran sel (Yu et al., 2015). Mikroba probiotik yang hidup di lambung harus toleran terhadap $\mathrm{pH} 3$ (Sanhueza et al., 2015) atau setidaknya pH 4, yang merupakan $\mathrm{pH}$ lapisan lendir lambung (García et al., 2017) dan pada konsentrasi garam empedu minimal 0,3\% (Shivram dan Vishwanath, 2012). Lebih dari 2 liter cairan lambung dan 1 liter empedu disekresikan tubuh dalam saluran pencernaan manusia setiap harinya.

Hasil uji ketahanan bakteri kandidat probiotik terhadap kondisi asam tersaji pada Tabel 2. Seluruh isolat memiliki viabilitas yang tinggi ( $>8 \log \mathrm{CFU} / \mathrm{mL}$ ) sebelum diinkubasi. Hasil penelitian menunjukkan lebih dari $95 \%$ populasi bakteri mampu bertahan pada kondisi asam kecuali isolat LIPI12-2-LAB033 dan LIPI13-2-LAB077. Populasi bakteri LIPI12-2LAB033 dan LIPI13-2-LAB077 mengalami penurunan viabilitas setelah diinkubasi yang tajam (5 siklus log). Asupan produk pangan dapat memberikan manfaat sebagai probiotik jika populasi bakteri probiotik mencapai 6-7 log CFU/g produk (Lähteinen et al., 2010). Sehingga kedua isolat tersebut dapat dikatakan tidak memiliki karakteristik sebagai probiotik. Lima isolat BAL yang lolos uji ketahanan media asam dilanjutkan dengan uji ketahanan garam empedu. Ketahanan terhadap asam juga berperan saat bakteri probiotik berada dalam makanan. Proses fermentasi menghasilkan asamasam organik yang dalam jumlah banyak akan menghambat pertumbuhan bakteri. Kondisi asam pada makanan dan dalam saluran pencernaan menjadi tantangan bakteri probiotik untuk bertahan hidup.

Bakteri dalam pertumbuhannya memerlukan $\mathrm{pH}$ optimum 6,5-7,5 (Maunatin dan Khanifa, 2012). Ketahanan hidup pada $\mathrm{pH}$ rendah berhubungan dengan kemampuan bakteri dalam mempertahankan kondisi internal sel dengan lingkungan luar. Ketahanan asam dapat meningkat dengan adanya pelindung alami dalam produk yang dikonsumsi seperti protein dan lemak.

Kemampuan untuk dapat bertahan hidup pada kondisi garam empedu konsentrasi tinggi merupakan syarat suatu isolat bakteri mampu membentuk koloni dan melakukan aktivitas metabolisme pada inangnya. Tabel 3 merupakan hasil uji ketahanan garam empedu pada isolat bakteri yang memiliki persentase tinggi pada uji ketahanan terhadap kondisi asam. Persentase bakteri yang bertahan pada uji ketahanan garam empedu ini masih tinggi. Namun terjadi penurunan viabilitas sel selama inkubasi $(4-12 \%)$ selama 24 jam. Menurunnya viabilitas sel disebabkan berkurangnya makanan dan mulai masuknya konsentrasi garam ke dalam sel bakteri.

Garam empedu merupakan senyawa amphipatik, yang memiliki sisi polar (hidrofilik) dan sisi non polar (hidrofobik). Karakteristik ini menyebabkan garam empedu dapat mengemulsifikasi lemak. Membran sel bakteri tersusun dari lipid dan asam lemak, dengan karakteristik garam empedu ini membran sel akan rusak. Konsentrasi garam empedu pada usus hasus dan usus besar cukup tinggi untuk menghambat pertumbuhan dan membunuh bakteri yang ada di saluran pencernaan. Konsentrasi 0,3\% adalah konsentrasi rata-rata garam empedu di saluran usus (Oluwajoba et al., 2013). Menurut Argyri et al. (2013) ketahanan hidup pada konsentrasi garam empedu tinggi berkaitan dengan dengan produksi enzim bile salt hidrolase (BSH). Enzim ini mampu menghidrolisis garam empedu dan menurunkan efek racunnya.

Tabel 2. Hasil uji ketahanan hidup pada kondisi asam

\begin{tabular}{|c|c|c|c|c|c|c|}
\hline \multirow{2}{*}{ No. } & \multirow{2}{*}{ Nomor Seri Isolat } & \multicolumn{4}{|c|}{ Jumlah Bakteri (log CFU/mL) setelah Inkubasi (Jam) } & \multirow{2}{*}{$\begin{array}{c}\text { Ketahanan Hidup } \\
(\%)\end{array}$} \\
\hline & & 0 & 4 & 8 & 24 & \\
\hline 1 & LIPI12-2-LAB004 & $9,20 \pm 0,16^{\text {वeह }}$ & $9,26 \pm 0,10^{\mathrm{aeA}}$ & $9,26 \pm 0,13^{\mathrm{aeA}}$ & $9,24 \pm 0,09^{\mathrm{aeA}}$ & 100,00 \\
\hline 2 & LIPI12-2-LAB030 & $9,30 \pm 0,09^{\text {eъ }}$ & $9,30 \pm 0,03^{\mathrm{eA}}$ & $9,49 \pm 0,27^{\mathrm{eA}}$ & $9,22 \pm 0,15^{\mathrm{eA}}$ & 99,14 \\
\hline 3 & LIPI12-2-LAB031 & $9,24 \pm 0,06^{\text {aes }}$ & $9,34 \pm 0,08^{\text {aee }}$ & $9,27 \pm 0,10^{\mathrm{ae \mu}}$ & $9,23 \pm 0,04^{\text {aee }}$ & 99,89 \\
\hline 4 & LIPI13-2-LAB087 & $9,13 \pm 0,03^{\text {cas }}$ & $9,15 \pm 0,04^{\mathrm{ca \mu}}$ & $9,03 \pm 0,02^{\mathrm{CaA}}$ & $8,79 \pm 0,03^{\mathrm{ca \mu}}$ & 96,28 \\
\hline 5 & LIPI13-2-LAB011 & $8,86 \pm 0,07^{\mathrm{CD}}$ & $8,85 \pm 0,06^{\mathrm{CA}}$ & $8,88 \pm 0,16^{\mathrm{CA}}$ & $8,78 \pm 0,02^{\mathrm{CA}}$ & 99,10 \\
\hline 6 & LIPI12-2-LAB033 & $8,92 \pm 0,02^{\mathrm{DD}}$ & $4,27 \pm 0,97^{\mathrm{DA}}$ & $4,02 \pm 0,49^{\mathrm{DA}}$ & $4,42 \pm 0,42^{\mathrm{DA}}$ & 49,55 \\
\hline 7 & LIPI13-2-LAB077 & $8,67 \pm 0,16^{\text {as }}$ & $3,78 \pm 0,16^{\text {аА }}$ & $3,18 \pm 0,08^{\text {ан }}$ & $2,84 \pm 0,08^{\text {ан }}$ & 32,76 \\
\hline
\end{tabular}

Keterangan: Data rata-rata diperoleh dari dari 2 kali ulangan perlakuan dengan 2 kali ulangan analisis. Superscript yang berbeda menunjukkan perbedaan yang nyata $(P<0,05)$. Huruf kapital dibaca horizontal (baris) dan huruf kecil dibaca vertikal (kolom) 
Tabel 3. Hasil uji ketahanan hidup terhadap garam empedu

\begin{tabular}{|c|c|c|c|c|c|c|}
\hline \multirow{2}{*}{ No. } & \multirow{2}{*}{ Nomor Seri Isolat } & \multicolumn{4}{|c|}{ Jumlah Bakteri (log CFU/mL) setelah Inkubasi (jam) } & \multirow{2}{*}{$\begin{array}{l}\text { Ketahanan } \\
\text { Hidup (\%) }\end{array}$} \\
\hline & & 0 & 4 & 8 & 24 & \\
\hline 1 & LIPI12-2-LAB004 & $9,14 \pm 0,25^{\mathrm{CD}}$ & $8,85 \pm 0,01^{\mathrm{CB}}$ & $8,64 \pm 0,11^{\mathrm{CB}}$ & $8,10 \pm 0,02^{\mathrm{CA}}$ & 88,62 \\
\hline 2 & LIPI12-2-LAB030 & $8,50 \pm 0,37^{\mathrm{DCD}}$ & $9,31 \pm 0,86^{\mathrm{DCD}}$ & $8,35 \pm 0,04^{\mathrm{DCD}}$ & $7,68 \pm 0,16^{\mathrm{DCA}}$ & 90,35 \\
\hline 3 & LIPI12-2-LAB031 & $8,21 \pm 0,40^{\mathrm{and}}$ & $8,40 \pm 0,35^{\mathrm{ado}}$ & $8,63 \pm 0,52^{\text {ado }}$ & $7,60 \pm 0,57^{\mathrm{aDH}}$ & 92,57 \\
\hline 4 & LIPI13-2-LAB087 & $8,08 \pm 0,06^{\text {ab }}$ & $8,40 \pm 0,08^{\text {ab }}$ & $8,63 \pm 0,13^{\text {ab }}$ & $7,60 \pm 0,02^{\mathrm{aA}}$ & 94,06 \\
\hline 5 & LIPI13-2-LAB011 & $8,53 \pm 0,16^{\mathrm{DCB}}$ & $8,67 \pm 0,10^{\mathrm{DCD}}$ & $8,58 \pm 0,28^{\mathrm{DCD}}$ & $8,19 \pm 0,19^{\mathrm{DCA}}$ & 96,01 \\
\hline
\end{tabular}

Keterangan: Data rata-rata diperoleh dari dari 2 kali ulangan perlakuan dengan 2 kali ulangan analisis. Superscript yang berbeda menunjukkan perbedaan yang nyata $(P<0,05)$. Huruf kapital dibaca horizontal (baris) dan huruf kecil dibaca vertikal (kolom)

Aktivitas BSH mampu meningkatkan kelangsungan hidup bakteri di usus dan memberikan karakteristik menguntungkan dari bakteri probiotik. Komponen dalam makanan juga dapat melindungi dan meningkatkan ketahanan bakteri dalam kondisi garam empedu.

Spesies bakteri yang lolos uji ketahanan hidup pada kondisi keasaman dan garam empedu tinggi adalah $L$. plantarum dan $L n$. mesenteroides. Hasil penelitian menunjukkan adanya perbedaan ketahanan pada kondisi asam dan garam empedu antar spesies dan antar asal isolat bakteri pada spesies yang sama $(P<0,05)$. Hal ini sama dengan pendapat Guo et al. (2009) yang menyatakan perbedaan daya tahan disebabkan oleh adanya perbedaan spesies dan galur spesifik. Sedangkan Guo et al. (2015) dalam penelitiannya menambahkan faktor kondisi lingkungan asal bakteri juga berpengaruh terhadap daya tahan tersebut. Pendapat berbeda disampaikan Ramasamy et al. (2012) yang menduga tidak ada hubungan antara ketahanan bakteri terhadap asam dengan sumber asal bakteri. Penelitian karakteristik probiotik ketahanan asam terhadap L. plantarum juga dilakukan oleh Maunatin dan Khanifa (2012) dan Argyri et al. (2013) yang menghasilkan viabilitas bakteri terhadap asam lebih dari 7 log $\mathrm{CFU} / \mathrm{mL}$. Shakibaie et al. (2017) melaporkan lebih dari $50 \%$ L. plantarum dapat bertahan hidup pada keasaman tinggi ( $\mathrm{pH} 2$ selama $3 \mathrm{jam})$. Yu et al. (2015) melaporkan ketahanan hidup 15 galur $L$. plantarum pada kondisi asam tinggi sebesar 67,28$96,13 \%$, dan 5 galur diantaranya mampu bertahan pada konsentrasi garam empedu $0,3 \%$. Penelitian Valente et al. (2019) juga menyebutkan L. plantarum yang diisolasi dari keju mempunyai karakteristik sebagai probiotik secara in vitro karena mampu bertahan terhadap media asam dan garam empedu. Pada uji ketahanan asam Ln. mesenteroides oleh Argyri et al. (2013) memberikan hasil yang berbeda, dari 17 galur yang diujikan hanya 1 galur yang memiliki viabilitas 1-3 log $\mathrm{CFU} / \mathrm{mL}$, sedangkan 16 lainnya dibawah 1 log CFU/mL.

Waktu inkubasi berpengaruh terhadap daya tahan isolat pada kondisi asam dan garam empedu $(P<0,05)$. Pada awal inkubasi, sebagian isolat masih mampu bertahan pada kondisi yang diujikan. Namun setelah 24 jam, terjadi penurunan signifikan dari pertumbuhan isolat baik pada kondisi asam maupun garam empedu. Akumulasi produksi asam organik, persaingan untuk mendapatkan sumber energi dan rusaknya membran sel menjadi penyebab menurunnya viabilitas isolat selama inkubasi.

\section{Hidrofobisitas isolat BAL}

Komponen penyusun dinding sel seperti fosfolipid dan lipopolisakarida berperan dalam interaksi hidrofobik sel bakteri. Tabel 4 menunjukkan nilai hidrofobisitas isolat dalam heksadekana yang tinggi (>99\%). Nilai hidrofobisitas yang tinggi menunjukkan adanya molekul hidrofob pada permukaan sel bakteri yang diuji. Bakteri dengan hidrofobisitas tinggi akan mampu tinggal dipermukaan usus, berkembang biak dan dapat masuk kedalam jaringan (Fardiaz dan Radiati, 2012). Nilai hidrofobisitas isolat pada penelitian ini lebih tinggi dibandingkan penelitian Ding et al. (2017). Penelitian Ding et al. (2017) menguji beberapa galur $L$. plantarum dan nilai hidrofobisitas tertinggi hanya $60,97 \%$. Menurut Panjaitan et al. (2018) hidrofobisitas mikroba dipengaruhi oleh galur bakteri, media pertumbuhan, umur bakteri dan struktur permukaan bakteri. Keragaman faktor tersebut menyebabkan setiap spesies dan galur mengekspresikan nilai hidrofobisitas yang berbeda (Fardiaz dan Radiati, 2012). Namun, hasil penelitian ini tidak sependapat dengan hasil yang disampaikan oleh Panjaitan et al. (2018) dan Fardiaz dan Radiati (2012). Pada penelitian ini, galur dan spesies isolat tidak berpengaruh terhadap nilai hidrofobisitas $(P>$ $0,05)$.

Tabel 4. Hasil uji hidrofobisitas

\begin{tabular}{ccc}
\hline No. & Nomor Seri Isolat & Hidrofobisitas $(\%)$ \\
\hline 1 & LIPI12-2-LAB004 & $99,64 \pm 0,00^{\mathrm{a}}$ \\
2 & LIPI12-2-LAB030 & $99,69 \pm 0,01^{\mathrm{a}}$ \\
3 & LIPI12-2-LAB031 & $99,60 \pm 0,08^{\mathrm{a}}$ \\
4 & LIPI13-2-LAB087 & $99,85 \pm 0,05^{\mathrm{a}}$ \\
5 & LIPI13-2-LAB011 & $99,54 \pm 0,25^{\mathrm{a}}$ \\
\hline
\end{tabular}

Keterangan: Superscript yang berbeda pada kolom yang sama menunjukkan perbedaan yang nyata $(P<0,05)$

\section{Penempelan isolat BAL pada lempeng tipis}

Kriteria penting lain dalam seleksi in vitro bakteri kandidat probiotik adalah kemampuannya untuk menempel di mukosa. Penempelan menunjukkan 
adanya interaksi hidrofobik yang melibatkan membran sel bakteri dan dinding permukaan sel inang (Fardiaz dan Radiati, 2012). Penempelan dapat didukung adanya penunjang adhesi seperti lektin. Salah satu yang mendukung penempelan adalah produksi eksopolisakarida (EPS) oleh bakteri (GarcíaRuiz et al., 2014).

Tabel 5. menunjukkan hasil uji penempelan secara ulas dan planktonic. Penurunan jumlah mikroba terjadi selama inkubasi. Isolat LIPI12-2-LAB004 memiliki kemampuan penempelan terbesar diantara lainnya. Kemampuan menempel yang baik akan memiliki kemampuan pembentukan biofim yang baik pula. Setelah inkubasi 48 jam, 5 isolat bakteri mengalami penurunan 4-6 log (ulas) dan 5-6 log (planktonic). Hasil ini disebabkan karena adanya gerakan saat inkubasi dan menurunnya konsentrasi nutrisi selama inkubasi.

Kemampuan menempel dipengaruhi oleh asal bakteri. Penelitian Todoriki et al. (2001) melaporkan Lactobacillus yang diisolasi dari saluran pencernaan mempunyai kemampuan menempel yang lebih baik dibandingkan Lactobacillus dari makanan hasil fermentasi. Fenomena ini terjadi pada hasil penelitian ini. Setelah pengujian selama 48 jam, hanya bakteri L. plantarum LIPI12-2-LAB004 (acar, Yogyakarta) yang masih melekat di lempeng tipis walaupun nilainya tidak begitu besar. $L$. plantarum lainnya tidak teridentifikasi jumlahnya $(<1)$. Kemampuan untuk menempel berlawanan dengan mekanisme peristaltis, sehingga jika bakteri yang tidak memiliki kemampuan ini akan keluar dari saluran pencernaan. Bakteri tidak akan membentuk koloni dan hilang kemampuannya dalam melawan invasi bakteri patogen dalam saluran pencernaan. Jenis dan asal isolat memengaruhi populasi isolat dengan metode ulas $(P<0,05)$. Keragaman asal bakteri memberikan karakteristik membran sel yang berbeda dari setiap isolat, sehingga kemampuan dalam menempel juga berbeda. Pada inkubasi 48 jam dengan metode planktonic, jenis dan asal isolat memberikan pengaruh yang signifikan pada populasi isolat $(P<0,05)$. Isolat $L$. plantarum yang berasal dari acar (Yogyakarta) memiliki kemampuan menempel yang lebih baik dibandingkan isolat lainnya.

\section{Koagregasi antar isolat BAL}

Uji koagregasi dilakukan untuk menentukan kemampuan interaksi antar isolat bakteri untuk saling menempel dalam saluran pencernaan dan tidak mudah tercuci oleh pergerakan usus. Pembentukan koloni sangat penting sebagai probiotik untuk menciptakan pertahanan kuat dari inang terhadap masuknya patogen dari luar (Peres et al., 2014).

Hasil penelitian (Tabel 6) menunjukkan adanya koagregasi antar isolat: LIPI12-2-LAB004, LIPI12-2LAB031, LIPI13-2-LAB087, dan LIPI13-2-LAB011 dengan persentase yang berbeda-beda (2,927,37\%). Isolat LIPI12-2-LAB030 tidak memberikan nilai koagregasi saat dipasangkan. Uji koagregasi spesies yang sama namun berbeda galur menghasilkan nilai yang berbeda pula. Menurut Bao et al. (2010) nilai koagregasi dipengaruhi oleh spesifik galur (morfologi), waktu inkubasi dan adanya inhibitor. Semakin lama waktu inkubasi koagregasi semakin tinggi.

Tabel 5. Hasil uji penempelan pada lempeng tipis

\begin{tabular}{|c|c|c|c|c|c|}
\hline \multirow{3}{*}{ No. } & \multirow{3}{*}{ Nomor Seri Isolat } & \multicolumn{4}{|c|}{ Jumlah Mikroba (log CFU/mL) } \\
\hline & & \multicolumn{2}{|c|}{24 Jam } & \multicolumn{2}{|c|}{$48 \mathrm{Jam}$} \\
\hline & & Ulas & Planktonik & Ulas & Planktonik \\
\hline 1 & LIPI12-2-LAB004 & $6,99 \pm 0,01^{0}$ & $9,23 \pm 0,08^{\mathrm{d}}$ & $2,46 \pm 0,04^{\circ}$ & $3,56 \pm 0,06^{\mathrm{u}}$ \\
\hline 2 & LIPI12-2-LAB030 & $6,93 \pm 0,03^{\mathrm{a}}$ & $9,44 \pm 0,01^{\mathrm{a}}$ & $<1^{\mathrm{a}}$ & $2,37 \pm 0,01^{\mathrm{a}}$ \\
\hline 3 & LIPI12-2-LAB031 & $6,62 \pm 0,23^{\circ}$ & $9,22 \pm 0,14^{\mathrm{a}}$ & $<1^{\mathrm{a}}$ & $2,18 \pm 0,08^{D}$ \\
\hline 4 & LIPI13-2-LAB087 & $7,23 \pm 0,08^{\circ}$ & $9,34 \pm 0,00^{\mathrm{a}}$ & $<1^{\mathrm{a}}$ & $2,61 \pm 0,06^{\mathrm{c}}$ \\
\hline 5 & LIPI13-2-LAB011 & $6,62 \pm 0,08^{a}$ & $9,30 \pm 0,08^{\mathrm{a}}$ & $<1^{\mathrm{a}}$ & $2,40 \pm 0,08^{D}$ \\
\hline
\end{tabular}

Keterangan: Data rata-rata diperoleh dari dari 2 kali ulangan perlakuan dengan 2 kali ulangan analisis. Superscript yang berbeda pada kolom yang sama menunjukkan perbedaan yang nyata $(P<0,05)$.

Tabel 6. Hasil uji koagregasi

\begin{tabular}{|c|c|}
\hline Pasangan Isolat & Persentase Koagregasi (\%) \\
\hline LIPI12-2-LAB004 dan LIPI12-2-LAB031 & $4,27 \pm 1,5$ \\
\hline LIPI12-2-LAB004 dan LIPI12-2-LAB030 & - \\
\hline LIPI12-2-LAB004 dan LIPI13-2-LAB087 & $7,37 \pm 2,8$ \\
\hline LIPI12-2-LAB004 dan LIPI13-2-LAB011 & $5,83 \pm 3,1$ \\
\hline LIPI12-2-LAB031 dan LIPI12-2-LAB030 & - \\
\hline LIPI12-2-LAB031 dan LIPI13-2-LAB087 & $6,10 \pm 3,0$ \\
\hline LIPI12-2-LAB031 dan LIPI13-2-LAB011 & $3,85 \pm 1,9$ \\
\hline LIPI12-2-LAB030 dan LIPI13-2-LAB087 & - \\
\hline LIPI12-2-LAB030 dan LIPI13-2-LAB011 & - \\
\hline LIPI13-2-LAB087 dan LIPI13-2-LAB011 & $2,92 \pm 0,6$ \\
\hline
\end{tabular}

Keterangan: Data rata-rata diperoleh dari dari 2 kali ulangan perlakuan dengan 2 kali ulangan analisis 


\section{KESIMPULAN}

BAL yang diuji dan diseleksi sebagai kandidat probiotik memiliki perbedaan pada ketahanan terhadap kondisi asam dan garam empedu, uji hidrofobisitas, uji penempelan, dan uji koagregasi. Spesies dan asal isolat memberikan pengaruh signifikan pada ketahanan hidup terhadap kondisi asam dan garam empedu serta viabilitas saat uji penempelan. Semakin lama waktu inkubasi, terjadi penurunan populasi isolat pada uji ketahanan kondisi asam, garam empedu dan penempelan (ulas dan planktonic). Isolat BAL yang memiliki karakteristik sebagai probiotik secara in vitro adalah $L$. plantarum LIPI122-LAB004, L. plantarum LIPI12-2-LAB031, L. plantarum LIPI13-2-LAB087 dan L. plantarum LIPI13-2LAB011.

\section{UCAPAN TERIMAKASIH}

Kegiatan penelitian ini merupakan bagian dari program TP Tasikmalaya dan Biovillage pada DIPA Pusat Penelitian Bioteknologi-LIPI.

\section{DAFTAR PUSTAKA}

Argyri AA, Zoumpopoulou G, Karatzas KAG, Tsakalidou E, Nychas GJE, Panagou EZ, Tassou CC. 2013. Selection of potential probiotic lactic acid bacteria from fermented olives by in vitro tests. Food Microbiol 33: 282-291. DOI: 10.10 16/j.fm.2012.10.005.

Bao Y, Zhang, Yanchao, Zhang, Yong, Liu Y, Wang S, Dong X, Wang Y, Zhang H. 2010. Screening of potential probiotic properties of Lactobacillus fermentum isolated from traditional dairy products. Food Control 21: 695-701. DOI: 10.1016/ j.foodcont.2009.10.010.

Canzi E, Guglielmetti S, Mora D, Tamagnini I, Parini C. 2005. Conditions affecting cell surface properties of human intestinal bifidobacteria. Antonie van Leeuwenhoek, Int J Gen Mol Microbiol 88: 207-219. DOI: 10.1007/s10482-005-6501-3.

Dewanti R, Wong ACL. 1995. Influence of culture conditions on biofilm formation by Escherichia coli O157:H7. Int J Food Microbiol 26: 147-164. DOI: 10.1016/0168-1605(94)00103-D.

Ding W, Shi C, Chen M, Zhou J, Long R, Guo X 2017. Screening for lactic acid bacteria in traditional fermented Tibetan yak milk and evaluating their probiotic and cholesterol-lowering potentials in rats fed a high-cholesterol diet. $J$ Funct Foods 32: 324-332. DOI: 10.1016/j.jff. 2017.03.021.
Fardiaz D, Radiati LE. 2012. Pengaruh whey kefir susu kambing terhadap hidrofobisitas bakteri $E$. coli 0157:H7, S. typhi dan khamir C. albicans. J Ilmu Teknol Hasil Ternak 7: 12-18.

Fijan S. 2014. Microorganisms with claimed probiotic properties: An overview of recent literature. Int J Environ Res Public Health 11: 4745-4767. DOI: 10.3390/ijerph110504745.

García-Ruiz A, González de Llano D, Esteban-Fernández $A$, Requena T, Bartolomé $B$, MorenoArribas MV. 2014. Assessment of probiotic properties in lactic acid bacteria isolated from wine. Food Microbiol 44: 220-225. DOI: 10.1016/j.fm. 2014.06.015.

García A, Navarro K, Sanhueza E, Pineda S, Pastene E, Quezada M, Henríquez K, Karlyshev A, Villena J, González C. 2017. Characterization of Lactobacillus fermentum UCO-979C, a probiotic strain with a potent anti-Helicobacter pylori activity. Electron J Biotechnol 25: 75-83. DOI: 10.1016/j.ejbt.2016.11.008.

Guo C, Zhang S, Yuan Y, Yue T. 2015. Comparison of lactobacilli isolated from Chinese suan-tsai and koumiss for their probiotic and functional properties. J Funct Foods 12: 294-302. DOI: 10.1016/j.jff.2014.11.029.

Guo Z, Wang J, Yan L, Chen W, Liu XM, Zhang, HP. 2009. In vitro comparison of probiotic properties of Lactobacillus casei Zhang, a potential new probiotic, with selected probiotic strains. LWTFood Sci Technol 42: 1640-1646. DOI: 10.10 16/j.Iwt.2009.05.025.

Hartini P, Purwanto H, Juliyarsi IY, Purwati E. 2019. Probiotic potential of lactic acid bacteria Lactobacillus fermentum Nbrc 15885 isolation from tempoyak in Padang Pariaman district, West Sumatera (Indonesia) to acid conditions, bile salts and antimicrobial activity. Int Res J Pharm 10: 70-73. DOI: 10.7897/2230-8407.100381.

Ismail YS, Yulvizar C. 2017. Isolasi, karakterisasi dan uji aktivitas antimikroba bakteri asam laktat dari fermentasi biji kakao (Theobroma cacao L.) Bioleuser 1: 45-53.

Kaur $M$, Singh $H$, Jangra $M$, Kaur $L$, Jaswal $P$, Dureja C, Nandanwar H, Chaudhuri SR, Raje M, Mishra S, Pinnaka AK. 2017. Lactic acid bacteria isolated from yak milk show probiotic potential. Appl Microbiol Biotechnol 101: 76357652. DOI: $10.1007 / \mathrm{s} 00253-017-8473-4$.

Kizerwetter-Świda M, Binek M. 2016. Assessment of potentially probiotic properties of Lactobacillus strains isolated from chickens. Polish J Vet Sci 19: 15-20. DOI: 10.1515/pjvs-2016-0003. 
Kos B, Šušković J, Vuković S, Šimpraga M, Frece J, Matošić S. 2003. Adhesion and aggregation ability of probiotic strain Lactobacillus acidophilus M92. J Appl Microbiol 94: 981-987. DOI: 10.1046/j.1365-2672.2003.01915.x.

Kumar BV, Vijayendra SVN, Reddy OVS. 2015. Trends in dairy and non-dairy probiotic products - a review. J Food Sci Technol 52: 6112-6124. DOI: 10.1007/s13197-015-1795-2.

Lähteinen T, Malinen E, Koort JMK, MertaniemiHannus U, Hankimo T, Karikoski N, Pakkanen $S$, Laine $H$, Sillanpää $H$, Söderholm $H$, Palva A. 2010. Probiotic properties of Lactobacillus isolates originating from porcine intestine and feces. Anaerobe 16: 293-300. DOI: 10.1016/j. anaerobe.2009.08.002.

Maunatin A, Khanifa, 2012. Uji potensi probiotik Lactobacillus plantarium secara in vitro. Alchemy-J Chem 2: 26-34. DOI: 10.18860/al.Wi0.2298.

Nuraida L. 2015. A review: Health promoting lactic acid bacteria in traditional Indonesian fermented foods. Food Sci Hum Wellness 4: 4755. DOI: 10.1016/j.fshw.2015.06.001.

Oluwajoba SO, Akinyosoye FA, Oyetayo VO. 2013. In vitro screening and selection of probiotic lactic acid bacteria isolated from spontaneously fermenting kunu-zaki. Adv Microbiol 3: 309-316. DOI: 10.4236/aim.2013.34044.

Panjaitan R, Nuraida L, Dewanti-Hariyadi R. 2018. Seleksi isolat bakteri asam laktat asal tempe dan tape sebagai kandidat probiotik. J Teknol Industri Pangan 29: 175-184. DOI: 10.6066/jtip. 2018.29.2.175.

Peres CM, Alves M, Hernandez-Mendoza A, Moreira L, Silva S, Bronze MR, Vilas-Boas L, Peres C, Malcata FX 2014. Novel isolates of lactobacilli from fermented Portuguese olive as potential probiotics. LWT-Food Sci Technol 59: 234-246. DOI: 10.1016/j.Iwt.2014.03.003.

Pundir RK, Rana S, Kashyap N, Kaur A. 2013. Probiotic potential of lactic acid bacteria isolated from food samples: An in vitro study. J Appl Pharm Sci 3: 85-93. DOI: 10.7324/JAPS.2013.3 0317.
Ramasamy K, Rahman NZA, Chin SC, Alitheen NJ, Abdullah N, Wan HY. 2012. Probiotic potential of lactic acid bacteria from fermented Malaysian food or milk products. Int J Food Sci Technol 47: 2175-2183. DOI: 10.1111/j.1365-2621.20 12.03085.x.

Sanhueza E, Paredes-Osses E, González CL, García A. 2015. Effect of pH in the survival of Lactobacillus salivarius strain UCO 979C wild type and the $\mathrm{pH}$ acid acclimated variant. Electron J Biotechnol 18: 343-346. DOI: 10.1016/j. ejbt.2015.06.005.

Shakibaie M, Mohammadi-Khorsand T, Adelisardou, M. 2017. Probiotic and antioxidant properties of selenium-enriched Lactobacillus brevis LSe isolated from an Iranian traditional dairy product. J Trace Elem Med Biol 40: 1-9. DOI: 10.1016/j.jtemb.2016.11.013.

Shivram PL, Vishwanath PP. 2012. Assessment of probiotic potential of Lactobacillus $\mathrm{sp}$. isolated from cheese and preparation of probiotic icecream. Int J Res Ayurveda Pharm 3: 532-536.

Todoriki K, Mukai T, Sato S, Toba T. 2001. Inhibition of adhesion of food-borne pathogens to Caco-2 cells by Lactobacillus strains. J Appl Microbiol 91: 154-159. DOI: 10.1046/j.1365-2672.2001. 01371.x.

Valente GL, Acurcio L, Freitas LV, Ricoli J, Silva A, Souza M, Penna CFA. 2019. Short communication: In vitro and in vivo probiotic potential of Lactobacillus plantarum B7 and Lactobacillus rhamnosus D1 isolated from Minas artisanal cheese. J Dairy Sci 102: 5957-5961. DOI: 10. 3168/jds.2018-15938.

Yang M, Jiang R, Liu M, Chen S, He L, Ao X, Zou L, Liu S, Zhou K. 2017. Study of the probiotic properties of lactic acid bacteria isolated from Chinese traditional fermented pickles. J Food Process Preserv 41: 1-7. DOI: 10.1111/jpp. 12954.

Yu HJ, Chen YF, Yang HJ, Yang J, Xue JG, Li CK, Kwok LY, Zhang HP, Sun TS. 2015. Screening for Lactobacillus plantarum with potential inhibitory activity against enteric pathogens. Annals Microbiol 65: 1257-1265. DOI: 10.1007/s13213014-0963-3. 